\title{
A convenient one pot synthesis of highly substituted piperidines through a Michael addition-aldol cyclization sequence
}

\author{
G. Ravindran, S. Muthusubramanian,* and S. Perumal \\ Department of Organic Chemistry, School of Chemistry, Madurai Kamaraj University, Madurai- \\ 625021, India \\ E-mail: muthumanian2001@yahoo.com
}

\begin{abstract}
A neat and rapid procedure is reported for the synthesis of a variety of (2-aroyl-5-hydroxy-1,3,5triaryl-4-piperidyl)(aryl)methanone $\mathbf{( 3 a - 3 g )}$ by the condensation of 2-[(2-oxo-2arylethyl)anilino]-1-aryl-1-ethanones $\mathbf{1}$ with different arylidene acetophenone $\mathbf{2}$ under microwave irradiation.
\end{abstract}

Keywords: N,N-Diphenacylaniline, piperidine, microwave irradiation, arylidene acetophenone

\section{Introduction}

The piperidine ring is a structural feature of many alkaloids and drug candidates and there were thousands of piperidine compounds mentioned in clinical and preclinical studies. ${ }^{1}$ The piperidine ring system is one of the commonest structural sub units in natural compounds. Several substituted piperidines display important biological properties like antiviral activity, ${ }^{2}$ antidepressant effects, ${ }^{3}$ cytotoxic activity ${ }^{4}$ and antimalarial activity. ${ }^{5}$ Some piperidine derivatives are used as neuroleptic agents. ${ }^{6}$

Optically active 4-substitued piperidine derivatives have been recently synthesized from meso-3-substituted glutaric anhydride with (S)-methylbenzylamine. ${ }^{7}$ An intramolecular antiMarkovnikov hydroamination of 1-(3-aminopropyl)vinylarenes resulted in the formation of 3arylpiperidines. $^{8}$ A novel diastereoselective approach to 2,4-disubstituted piperidines involving the radical cyclization of 7-substituted 6-aza-8-bromooct-2-enoates has been recently reported. ${ }^{9}$ Stereoselective syntheses of several differently functionalized piperidines have been recently reported. ${ }^{10-14}$ Due to the importance of the piperdine chemistry, simple procedures for the formation of piperidines are highly desirable. In the present work, we describe an easy one pot synthesis of highly substituted piperidines from substituted N,N-diphenacylaniline $\mathbf{1}$. 


\section{Results and Discussion}

In continuation to our exploration on the synthetic utility of N,N-diphenacylaniline, ${ }^{15-18}$ we investigated the reaction of this substrate with chalcones in the presence of a base. A mixture of 2-[(2-oxo-2-arylethyl)anilino]-1-aryl-1-ethanones $\mathbf{1}$ with different arylidene acetophenone $\mathbf{2}$ and a catalytic amount of sodium ethoxide was taken in a glass tube and mixed thoroughly. The conversion of the reactants is not appreciable at room temperature or even at elevated temperature after sufficient time, though the formation of a single product 3 has been detected. However, when the open glass tube was immersed partially in a silica bath kept in a microwave oven and irradiated for three minutes duration at power level 4 in a total scale of 5 (Scheme 1), appreciable reaction took place and the products formed were found to be piperidine derivatives 3 by NMR spectral measurements (vide infra). All the piperidines $\mathbf{3}$ synthesised in the present work are hitherto unreported.

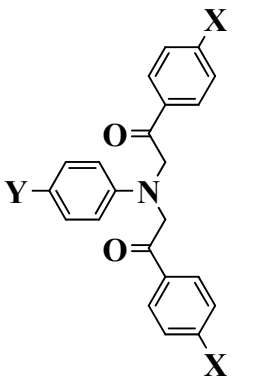

1

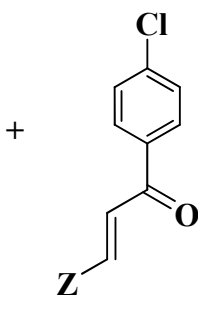

2

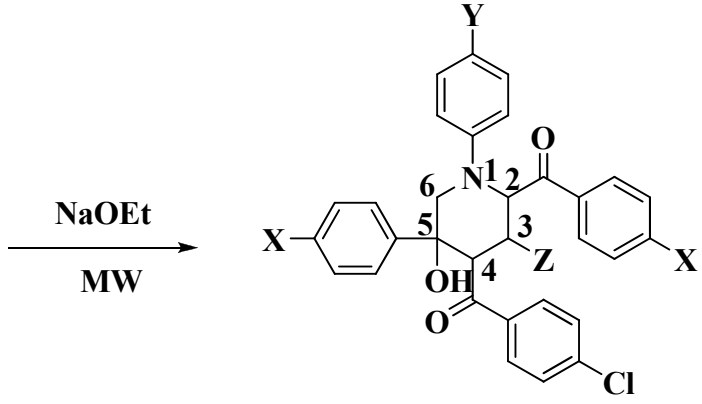

3

X $\quad$ Y $\quad$ Z

$\begin{array}{cccll} & \text { a } & \mathrm{H} & \mathrm{Me} & \text { 4-Chlorophenyl } \\ & \text { b } & \mathrm{Me} & \mathrm{H} & \text { 4-Chlorophenyl } \\ \text { c } & \mathrm{Me} & \mathrm{Me} & \text { 4-Chlorophenyl } \\ & \text { d } & \mathrm{Cl} & \mathrm{Me} & \text { 4-Chlorophenyl } \\ \text { e } & \mathrm{Me} & \text { 2-Thienyl } & \\ & \text { f } & \mathrm{Me} & \mathrm{OMe} & \text { 4-Chlorophenyl } \\ & \text { g } & \mathrm{Me} & \mathrm{Me} & \text { 4-Methoxyphenyl }\end{array}$

\section{Scheme 1}

The synthesized piperidines are all characterized by NMR spectral data. The ${ }^{1} \mathrm{H}$ NMR spectrum of $\mathbf{3 d}$ has a methyl signal at $2.19 \mathrm{ppm}$. The presence of five aromatic rings can also be inferred from the signal intensity in the aromatic region. This is also confirmed by the presence of ten $\mathrm{CH}$ carbons and ten quaternary carbons in the aromatic region of the ${ }^{13} \mathrm{C}$ NMR spectrum of 3d apart from the methyl carbon. Signals due to two carbonyl carbons are also there at 196.6 and $203.1 \mathrm{ppm}$. A signal appearing at $5.11 \mathrm{ppm}$, accounting for one hydrogen, gets exchanged with $\mathrm{D}_{2} \mathrm{O}$ indicating this hydrogen to be probably $\mathrm{OH}$. 
Apart from the signals listed above, three signals are noticed in the ${ }^{1} \mathrm{H}$ NMR spectrum and five signals are noticed in the ${ }^{13} \mathrm{C}$ NMR spectrum - three of them are methine, one is methylene and the other one is quaternary (from DEPT experiment). The presence AB pattern at 3.35 and $3.55 \mathrm{ppm}$ accounts for two hydrogens with a coupling of $12.6 \mathrm{~Hz}$. These two hydrogens have the same $\mathrm{C}, \mathrm{H}-\mathrm{COSY}$ relationship with the carbon at $66.1 \mathrm{ppm}$. There is a two hydrogen multiplet, slightly broadened, around $4.3 \mathrm{ppm}$, which has HETCOR connection with the carbons at 46.0 ppm and $55.1 \mathrm{ppm}$. The presence of two methine systems with probably identical proton chemical shift, but with different carbon chemical shift can be inferred. There is another one hydrogen signal, a doublet, appearing at $4.77 \mathrm{ppm}$ - having a coupling of $9.3 \mathrm{~Hz}$ - with one bond $\mathrm{CH}$ connectivity with the carbon at $73.7 \mathrm{ppm}$. Thus a $\mathrm{CH}_{2}$ group, three $\mathrm{CH}$ group and a quartenary carbons are there apart from the groups identified in the previous paragraph. It is very easy to construct the structure of the product at this stage and it is the piperidine derivative (2aroyl-5-hydroxy-1,3,5-triaryl-4-piperidyl)(aryl)methanone 3 and not 4 (Figure 1).

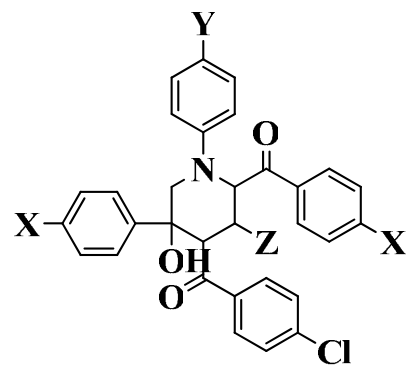

3

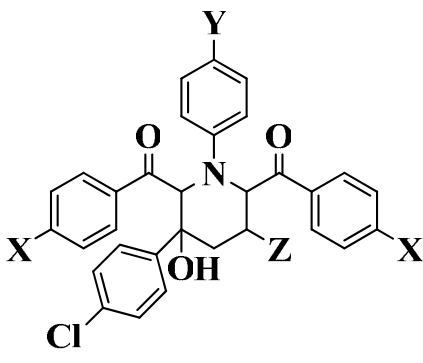

4

\section{Figure 1}

By logic, the hydrogen at $4.77 \mathrm{ppm}$ can be assigned to C-2 position as it is flanked between a carbonyl and a nitrogen atom getting deshielded compared to other methine hydrogens. As this hydrogen has a coupling constant of $9.3 \mathrm{~Hz}$ with the vicinal hydrogen at C-3, it can be arrived at that these two hydrogens are axially located in an assumed chair form of the piperidine ring. As the hydrogens at C-3 and C-4 appear together, the coupling between these two hydrogens are not clearly noticed. However the substituent at $\mathrm{C}-4$ can be assumed to have an equatorial orientation.

Another interesting feature noticed in the $\mathrm{H}, \mathrm{H}-\mathrm{COSY}$ spectrum of $\mathbf{3 d}$ is the connectivity between the shielded hydrogen of the methylene pair at $3.35 \mathrm{ppm}$ with the hydroxyl hydrogen and the hydrogen at $4.77 \mathrm{ppm}$. This latter connectivity establishes the assumption that the hydrogen at $4.77 \mathrm{ppm}$ is that at $\mathrm{C}-2$. The observed connections may be due to the weak four bond coupling in both cases. It must be mentioned that no visible coupling is seen between these hydrogens in the ${ }^{1} \mathrm{H}$ NMR spectrum. Another striking feature is the presence of only one deshieled doublet at $8.24 \mathrm{ppm}$ beyond $7.50 \mathrm{ppm}$ - due to the ortho hydrogens of one of the aroyl group - leaving the other shielded. The carbonyl carbon at $196.6 \mathrm{ppm}$ has HMBC contour with the hydrogens at $8.24 \mathrm{ppm}$ and the carbon at $203.1 \mathrm{ppm}$ has HMBC connection with the hydrogens at $7.20 \mathrm{ppm}$. The carbon at 196.6 has also HMBC connection with the hydrogen at 
$4.77 \mathrm{ppm}$, which has been assigned to $\mathrm{C}-2$ hydrogen. Hence the carbonyl carbon at $196.6 \mathrm{ppm}$ is due the aroyl group at C-2 and the ortho hydrogens of this aroyl group is heavily deshielded. The other carbonyl carbon at $203.1 \mathrm{ppm}$, therefore, must be due to the aroyl group at C-4 position and it is the ortho hydrogens belonging to this aroyl group that have been shielded. Due to the presence of three substituents at the vicinal carbons, this aroyl group may feel the steric effect and the aryl group would have gone out of plane with respect to the carbonyl - thereby a) loosing the conjugation and hence the carbonyl carbon appearing in the deshileded region and $b$ ) the ortho hydrogens not feeling the anisotropic deshielding but shielding of the carbonyl moiety leading to upfield shift of these hydrogens.

This reaction presumably proceeds via a tandem sequence involving Michael addition- aldol reaction ring closure as described in Scheme 2. Sodium ethoxide has been found to be a good catalyst compared to other organic bases for this reaction.
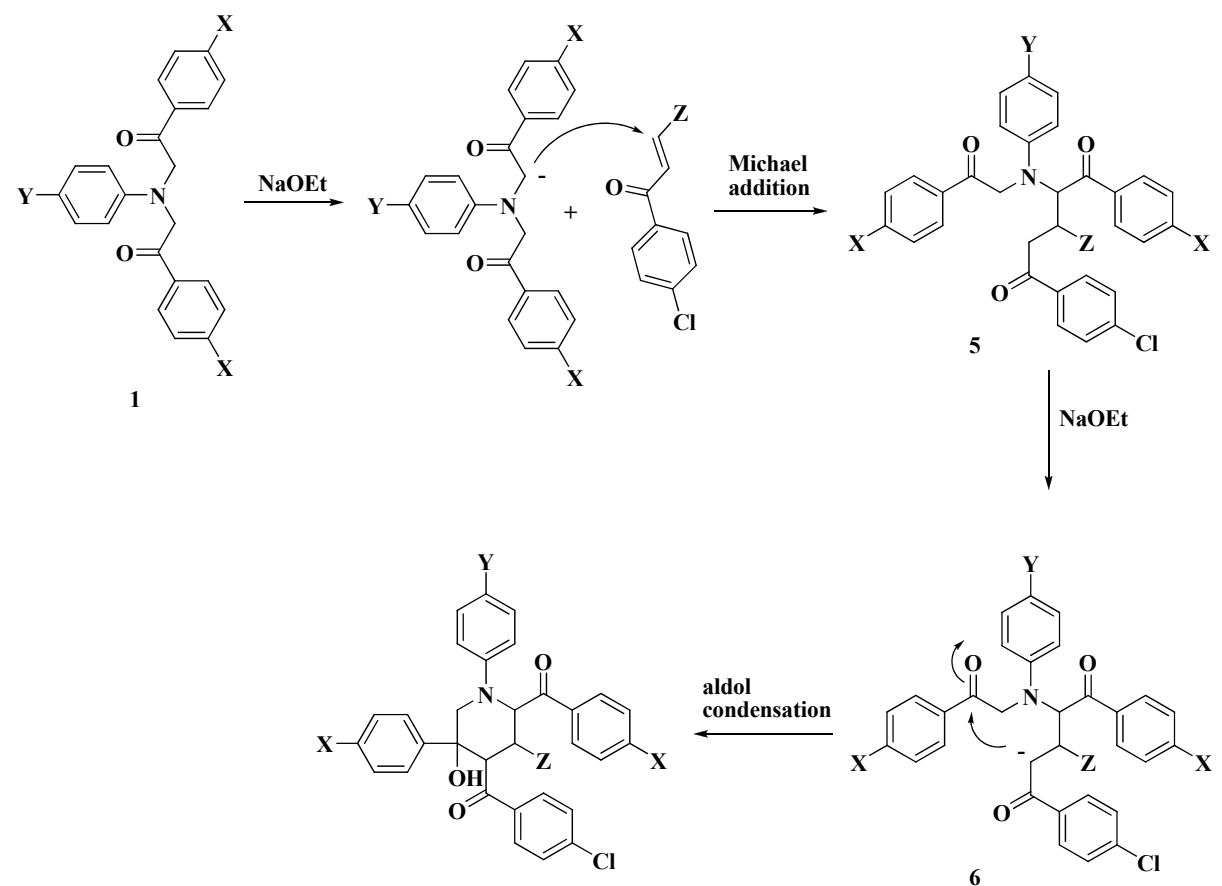

3

\section{Scheme 2}

The suggested mechanism envisages a Michael addition to chalcone affording the 5, which upon reaction with base can generate carbanion $\mathbf{6}$. The formation of piperidine derivatives $\mathbf{3}$ in this reaction indicates that the carbanion 6 undergoes intramolecular-aldol condensation leading to (2-aroyl-5-hydroxy-1,3,5-triaryl-4-piperidyl)(aryl)methanone 3. The compound $\mathbf{5}$ has two acidic hydrogens in different positions and both can form carbanions (6 and 7, Figure 2). The carbanion 7 is more stable and less reactive because of the inductive effect of the nearby nitrogen atom. The other carbanion 6 is relatively more reactive forming the product. 


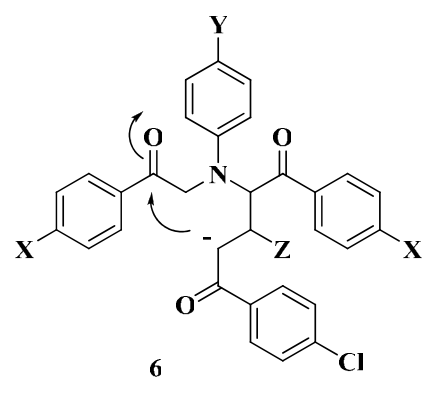

favourable

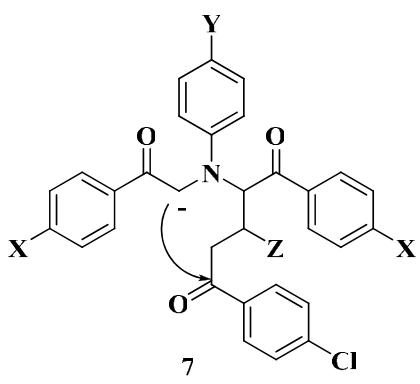

not-favourable

Figure 2

Thus a rapid one-pot tandem protocol has been developed for the synthesis of novel piperidine 3 from diphenacyl anilines and chalcone in the presence of sodium ethoxide.

\section{Experimental Section}

General procedures. All melting points were recorded in open capillaries and are uncorrected. The ${ }^{1} \mathrm{H}$, and ${ }^{13} \mathrm{C}$ NMR spectra were recorded on a Bruker $300 \mathrm{MHz}$ spectrometer at $300 \mathrm{MHz}$ and $75 \mathrm{MHz}$ respectively in $\mathrm{CDCl}_{3}$ using TMS as internal standard. The related 2D NMR spectra also recorded on the same instrument. Chemical shifts are given in parts per million $(\delta$-scale) and coupling constants are given in Hertz. A domestic microwave oven operating at $230 \mathrm{~V}$ and 50 $\mathrm{Hz}$ with consumption of $1000 \mathrm{~W}$ with a microwave power level $600 \mathrm{~W}$ and microwave frequency $2450 \mathrm{MHz}$ was employed. Micro analysis was carried out on a Perkin-Elmer instrument. All chromatographic separations were performed on 60-120 mesh silica gel using petroleum ether - ethyl acetate (95:5) as eluent.

\section{General procedure for the preparation of (2-aroyl-5-hydroxy-1,3,5-triaryl-4- piperidyl)(aryl)methanone (3)}

A mixture of 2-[(2-oxo-2-arylethyl)anilino]-1-aryl-1-ethanones 1 (1 mmol), arylidene acetophenone $2(1 \mathrm{mmol})$ and a catalytic amount of sodium ethoxide was taken in a glass tube and mixed thoroughly. The open glass tube was then immersed partially in a silica bath and microwave irradiated for 3 minutes at power level 4 in a total scale of 5 . After the irradiation, the reaction mixture was allowed to cool to room temperature. The maximum temperature of the silica bath, measured immediately after the reaction was over, was found to be $78^{\circ} \mathrm{C}$. The completion of the reaction was monitored by tlc and the product obtained was recrystallized from ethanol.

\section{2-Benzoyl-3-(4-chlorophenyl)-5-hydroxy-1-(4-methylphenyl)-5-phenyl-4-piperidyl](4-} chlorophenyl)methanone (3a).Yield: $76 \%$; Mp: $192{ }^{\circ} \mathrm{C} ;{ }^{1} \mathrm{H} \mathrm{NMR}\left(\mathrm{CDCl}_{3}\right): \delta 2.18(3 \mathrm{H}, \mathrm{s}), 3.49$ $(1 \mathrm{H}, \mathrm{d}, J=12.3 \mathrm{~Hz}), 3.61(1 \mathrm{H}, \mathrm{d}, J=12.6 \mathrm{~Hz}), 4.22-4.41(2 \mathrm{H}, \mathrm{m}), 4.85$ (1H, d, $J=9.3 \mathrm{~Hz})$, 
$4.95(1 \mathrm{H}, \mathrm{s}), 6.99-7.53(20 \mathrm{H}, \mathrm{m}), 8.15(2 \mathrm{H}, \mathrm{d}, J=7.2 \mathrm{~Hz}) .{ }^{13} \mathrm{C} \mathrm{NMR}\left(\mathrm{CDCl}_{3}\right): \delta 20.6,46.2,58.7$, $66.2,73.8,78.8,122.3,125.0,125.5,127.6,127.8,128.1,128.3,128.7,129.0,129.2,129.5$, 129.8, 130.0, 133.0, 133.1, 133.3, 135.5, 136.0, 139.6, 142.7, 194.2, 202.6. Anal. Calcd. for $\mathrm{C}_{38} \mathrm{H}_{31} \mathrm{Cl}_{2} \mathrm{NO}_{3}$ : C, 73.55; H, 5.03; N, 2.26. Found: C, 73.49; H, 5.07; N, 2.20 .

(4-Chlorophenyl)[3-(4-chlorophenyl)-5-hydroxy-2-(4-methylbenzoyl)-5-(4-methylphenyl)-1phenyl-4-piperidyl]methanone (3b). Yield: $74 \%$; Mp: $178{ }^{\circ} \mathrm{C} ;{ }^{1} \mathrm{H}$ NMR $\left(\mathrm{CDCl}_{3}\right): \delta 2.26(3 \mathrm{H}$, s), $2.30(3 \mathrm{H}, \mathrm{s}), 3.57(1 \mathrm{H}, \mathrm{d}, \quad J=10 \mathrm{~Hz}), 3.96(1 \mathrm{H}, \mathrm{d}, J=10 \mathrm{~Hz}), 4.21-4.43(2 \mathrm{H}, \mathrm{m}), 4.74$ $(1 \mathrm{H}, \mathrm{d}, J=9.9 \mathrm{~Hz}), 5.34(1 \mathrm{H}, \mathrm{s}), 6.70(2 \mathrm{H}, \mathrm{d}, J=8.4 \mathrm{~Hz}), 6.92-7.48(17 \mathrm{H}, \mathrm{m}), 8.28(2 \mathrm{H}, \mathrm{d}, J=$ $8.7 \mathrm{~Hz}) .{ }^{13} \mathrm{C}$ NMR $\left(\mathrm{CDCl}_{3}\right): \delta 20.6,21.5,47.3,54.0,66.6,74.0,77.8,122.5,126.3,126.5,126.8$, 127.9, 128.0, 128.3, 128.4, 128.5, 128.6, 128.8, 128.9, 129.1, 129.3, 129.4, 129.6, 129.8, 131.0, 136.4, 144.7, 193.7, 201.4. Anal. Calcd. for $\mathrm{C}_{39} \mathrm{H}_{33} \mathrm{Cl}_{2} \mathrm{NO}_{3}$ : C, 73.81; H, 5.24; N, 2.21. Found: $\mathrm{C}$, $73.89 ; \mathrm{H}, 5.27 ; \mathrm{N}, 2.20$.

\section{(4-Chlorophenyl)[3-(4-chlorophenyl)-5-hydroxy-2-(4-methylbenzoyl)-1,5-bis(4-}

methylphenyl)-4-piperidyl]methanone (3c). Yield: $80 \%$; Mp: $182{ }^{\circ} \mathrm{C} ; \quad{ }^{1} \mathrm{H}$ NMR $\left(\mathrm{CDCl}_{3}\right)$ : $\$ 2.20(6 \mathrm{H}, \mathrm{s}), 2.36(3 \mathrm{H}, \mathrm{s}), 3.44(1 \mathrm{H}, \mathrm{s}, \quad J=12.9 \mathrm{~Hz}), 3.58(1 \mathrm{H}, \mathrm{d}, J=12.3 \mathrm{~Hz}), 4.21-4.34(2 \mathrm{H}$, m), $4.79(1 \mathrm{H}, \mathrm{d}, J=9.0 \mathrm{~Hz}), 4.95(1 \mathrm{H}, \mathrm{s}), 6.99-7.37(18 \mathrm{H}, \mathrm{m}), 8.09(2 \mathrm{H}, \mathrm{d}, J=7.2 \mathrm{~Hz}) .{ }^{13} \mathrm{C}$ NMR $\left(\mathrm{CDCl}_{3}\right): \delta 20.6,20.8,21.7,46.3,56.0,66.4,73.4,73.9,122.3,124.8,128.3,128.7,129.0$, $129.1,129.5,129.8,132.8,133.0,133.3,136.2,136.5,137.4,137.6,138.3,139.5,139.9,143.8$, 147.7, 197.6, 203.4. Anal. Calcd. for $\mathrm{C}_{40} \mathrm{H}_{35} \mathrm{Cl}_{2} \mathrm{NO}_{3}$ : C, 74.07; H, 5.44; N, 2.16. Found: C, 74.09; $\mathrm{H}, 5.47 ; \mathrm{N}, 2.20$.

2-(4-Chlorobenzoyl)-3,5-bis(4-chlorophenyl)-5-hydroxy-1-(4-methylphenyl)-4-piperidyl](4chlorophenyl)methanone (3d). Yield: $74 \%$; Mp: $188{ }^{\circ} \mathrm{C}$; ${ }^{1} \mathrm{H}$ NMR $\left(\mathrm{CDCl}_{3}\right): \delta 2.19(3 \mathrm{H}, \mathrm{s})$, $3.35(1 \mathrm{H}, \mathrm{d}, J=12.3 \mathrm{~Hz}), 3.55(1 \mathrm{H}, \mathrm{d}, J=12.9 \mathrm{~Hz}), 4.22-4.33(2 \mathrm{H}, \mathrm{m}), 4.77(1 \mathrm{H}, \mathrm{d}, J=9.3$ $\mathrm{Hz}), 5.11(1 \mathrm{H}, \mathrm{s}), 7.01-7.46(18 \mathrm{H}, \mathrm{m}), 8.24(2 \mathrm{H}, \mathrm{d}, J=8.1 \mathrm{~Hz}) \cdot{ }^{13} \mathrm{C}$ NMR $\left(\mathrm{CDCl}_{3}\right): \delta 20.6,46.0$, $55.1,66.1,73.7,78.5,112.1,122.6,126.4,126.6,128.0,128.3,128.5,128.6,128.8,129.0,129.4$, 130.0, 130.1, 131.0, 133.3, 133.6, 135.6, 139.4, 140.1, 141.3, 196.6, 203.1. Anal. Calcd. for $\mathrm{C}_{38} \mathrm{H}_{29} \mathrm{Cl}_{4} \mathrm{NO}_{3}$ : C, 66.20; H, 4.24; N, 2.03. Found: C, 66.24; H, 5.27; N, 2.08.

(4-Chlorophenyl)[5-hydroxy-1-(4-methoxyphenyl)-2-(4-methylbenzoyl)-5-(4-

methylphenyl)-3-(2-thienyl)-4-piperidyl]methanone (3e).Yield: $68 \%$; Mp: $174{ }^{\circ} \mathrm{C}$; ${ }^{1} \mathrm{H}$ NMR $\left(\mathrm{CDCl}_{3}\right): \delta 2.19(3 \mathrm{H}, \mathrm{s}), 2.23(3 \mathrm{H}, \mathrm{s}), 2.39(3 \mathrm{H}, \mathrm{s}), 3.49(1 \mathrm{H}, \mathrm{d}, J=10.2 \mathrm{~Hz}), 4.03(1 \mathrm{H}, \mathrm{d}, J$ $=10.2 \mathrm{~Hz}), 4.21-4.34(2 \mathrm{H}, \mathrm{m}), 4.68(1 \mathrm{H}, \mathrm{d}, J=9.6 \mathrm{~Hz}), 4.90(1 \mathrm{H}, \mathrm{s}), 6.14-7.90(17 \mathrm{H}, \mathrm{m}), 8.12$ $(2 \mathrm{H}, \mathrm{d}, J=7.8 \mathrm{~Hz}) .{ }^{13} \mathrm{C} \mathrm{NMR}\left(\mathrm{CDCl}_{3}\right): \delta 20.3,20.6,21.7,45.2,58.1,66.3,75.0,76.3,112.8$, $122.8,124.9,125.4,126.8,127.0,127.9,128.4,128.6,128.7,128.8,129.5,129.7,132.7,135.3$, 136.1, 137.4, 138.6, 139.0, 144.5, 196.4, 202.6. Anal. Calcd. for $\mathrm{C}_{38} \mathrm{H}_{34} \mathrm{ClNO}_{3} \mathrm{~S}: \mathrm{C}, 73.59 ; \mathrm{H}$, 5.53; N, 2.26. Found: C, 73.60; H, 5.57; N, 2.28 .

(4-Chlorophenyl)[3-(4-chlorophenyl)-5-hydroxy-1-(4-methoxyphenyl)-2-(4-methylbenzoyl)5-(4-methylphenyl)-4-piperidyl]methanone (3f). Yield: 71\%; Mp: $185^{\circ} \mathrm{C} ;{ }^{1} \mathrm{H} N M R\left(\mathrm{CDCl}_{3}\right)$ : $\oint 2.17(3 \mathrm{H}, \mathrm{s}), 2.33(3 \mathrm{H}, \mathrm{s}), 3.36-3.48(2 \mathrm{H}, \mathrm{m}), 3.64(3 \mathrm{H}, \mathrm{s}), 4.30(2 \mathrm{H}, \mathrm{s}), 4.67(1 \mathrm{H}, \mathrm{s}), 4.99(1 \mathrm{H}$, s), $6.67(2 \mathrm{H}, \mathrm{d}, J=8.1 \mathrm{~Hz}), 6.97-7.43(16 \mathrm{H}, \mathrm{m}), 8.09(2 \mathrm{H}, \mathrm{d}, J=7.8 \mathrm{~Hz}) .{ }^{13} \mathrm{C} \mathrm{NMR}\left(\mathrm{CDCl}_{3}\right)$ : $\oint 20.8,21.7,46.2,55.2,56.0,67.1,73.7,74.5,114.3,124.8,125.0,128.2,128.6,128.9,129.0$, 
129.1, 129.4, 129.8, 132.9, 133.2, 135.8, 136.1, 137.3, 139.4, 139.7, 143.2, 143.8, 156.2, 197.5, 203.1. Anal. Calcd. for $\mathrm{C}_{40} \mathrm{H}_{35} \mathrm{Cl}_{2} \mathrm{NO}_{4}$ : C, 72.29; H, 5.31; N, 2.11. Found: C, 72.30; H, 5.37; N, 2.15 .

(4-Chlorophenyl)[5-hydroxy-3-(4-methoxyphenyl)-2-(4-methylbenzoyl)-1,5-bis(4methylphenyl)-4-piperidyl]methanone (3g). Yield: $73 \%$; $\mathrm{Mp}: 189{ }^{\circ} \mathrm{C}$; ${ }^{1} \mathrm{H} \mathrm{NMR}\left(\mathrm{CDCl}_{3}\right)$ : $\oint 2.19(6 \mathrm{H}, \mathrm{s}), 2.35(3 \mathrm{H}, \mathrm{s}), 3.42(1 \mathrm{H}, \mathrm{d}, \quad J=11.1 \mathrm{~Hz}), 3.56(3 \mathrm{H}, \mathrm{s}), 3.65(1 \mathrm{H}, \mathrm{m}), 4.25(2 \mathrm{H}$, $\mathrm{m}), 4.82(1 \mathrm{H}, \mathrm{d}, J=9.3 \mathrm{~Hz}), 5.01(1 \mathrm{H}, \mathrm{s}), 6.55(2 \mathrm{H}, \mathrm{d}, J=8.4 \mathrm{~Hz}), 6.98-7.38(16 \mathrm{H}, \mathrm{m}), 8.11$ $(2 \mathrm{H}, \mathrm{d}, J=6.9 \mathrm{~Hz}) .{ }^{13} \mathrm{C} \mathrm{NMR}\left(\mathrm{CDCl}_{3}\right): \delta 20.6,20.8,21.6,46.0,55.0,56.1,66.0,73.5,74.0$, $113.8,122.1,124.8,128.1,128.8,128.9,129.1,129.4,129.5,129.7,129.9,132.6,133.1,136.4$, 137.1, 140.3, 143.4, 144.2, 147.9, 158.6, 197.9, 204.0. Anal. Calcd. for $\mathrm{C}_{41} \mathrm{H}_{38} \mathrm{ClNO}_{4}$ : C, 76.44; H, 5.95; N, 2.17. Found: C, 76.40; H, 5.97; N, 2.15.

\section{Acknowledgements}

The authors thank the Department of Science and Technology, New Delhi for funding under the IRHPA program for the creation of the NMR facility.

\section{References}

1. Watson, P. S.; Jiang, B.; Scott, B. Org. Lett. 2000, 2, 3679.

2. Finke, P. E.; Oates, B.; Mills, S. G.; MacCoss, M.; Malkowitz, L.; Springer, M. S.; Gould, S. L.; Demartino, J. A.; Carella, A.; Carver, G.; Holmes, K.; Danzeisen, R.; Hazuda, D.; Kessler, J.; Lineberger, J.; Miller, M.; Schleif, W. A.; Emini, E. A. Bioorg. Med. Chem. Lett. 2001, 11, 2475.

3. Trabaco, A. A.; Aerts, N.; Alvarez, R. M.; Andres, J. I.; Boeckx, I.; Fernandez, J.; Gomez, A.; Janssens, F. E.; Leenaerts. J. E.; Lucas, A. I. D.; Matesanz, E.; Steckler, T.; Pullan, S. Bioorg. Med. Chem. Lett. 2007, 17, 3860.

4. (a) Kobayashi, J.; Ishibashi, M. Heterocycles. 1996, 42, 943. (b) Ninomiya, I.; Kiguchi, T.; Naito, T. Alkaloids 1998, 50, 317.

5. (a) Murata, K.; Takano, F.; Fushiya, S.; Oshima, Y. J. Nat. Prod. 1998, 61, 729. (b) Kobayashi, S.; Ueno, M.; Suzuki, R.; Ishitani, H.; Kim, H. S.; Wataya, Y. J. Org. Chem. 1999, 64, 6833. (c) Takaya, Y.; Tasaka, H.; Chiba, T.; Uwai, K.; Tanitsu, M.; Kim, H. S.; Wataya, Y.; Miura, M.; Takeshita, M.; Oshima, Y. J. Med. Chem. 1999, 42, 3163.

6. Boswell, R. F.; Welstead, W. J.; Duncan, R. L.; Johnson, D. N.; Funderburk, W. H. J. Med. Chem. 1978, 21, 136.

7. Liu, L. T.; Hong, P. C.; Huang, H. L.; Chen, S. F.; Wang, C. L. J.; Wen, Y. S. Tetrahedron: Asymmetry 2001, 12, 419.

8. Takemiya, A.; Hartwig, J. F. J. Am. Chem. Soc. 2006, 128, 6042. 
9. Gandon, L. A.; Russel, A. G.; Guveli, T.; Brodwolf, A. E.; Kariuki, B. M.; Spencer, N.; Snaith, J. S. J. Org. Chem. 2006, 71, 5198.

10. Figueiredo, R. M. D.; Frohlich, R.; Christmann, M. J. Org. Chem, 2006, 71, 4147.

11. Hu, X. E.; Kim, N. K.; Ledoussal, B. Org. Lett. 2002, 4, 4499.

12. Singh, O. V.; Han, H. Org. Lett. 2004, 6, 3067.

13. Lam, H. W.; Murray, G. J.; Firth, J. D. Org. Lett. 2005, 7, 5743.

14. Tailor, J.; Hall, D. G. Org. Lett. 2000, 2, 3715.

15. Ravindran, G.; Muthusubramanian, S.; Selvaraj, S.; Perumal, S. Indian. J. Chem., Sec. B. 2007, 46B, 1047.

16. Ravindran, G.; Muthusubramanian, S.; Selvaraj, S.; Perumal, S. Arkivoc 2007, xiii, 23.

17. Ravindran, G.; Muthusubramanian, S.; Selvaraj, S.; Perumal, S. Phosphorous Sulfur and Silicon Relat, Elem. 2007, 182, 509.

18. Ravindran, G.; Muthusubramanian, S.; Selvaraj, S.; Perumal, S. J. Heterocycl. Chem. 2007, 44, 133. 